\title{
一般均衡モデルによる日本の大都市のアメニティ評価
}

\author{
大 城 純 男*
}

1. は じめに

\section{1 研究のねらい}

近年，日本の大都市において，「都心回帰」といわれる再都市化が指摘され，住民の大都市への選好度 が高まってきているといわれている。しかし，歴史的にみれば，時代や時期によって，住民が居住地と して，都市と地方のいずれを選好するのか，都心か郊外か，また，都市のどのようなアメニティ和にウ イトを置いて評価しているのか，などはたえず変化してきたと考えられる。

本研究では，このような視点から，傊金と地代の一般均衡モデルによる日本の大都市のアメニティ䚻 属価額を 3 期にわたって推計し，住民や企業がどのようなアメニティを評価し，また，どのような都市 を選好してきたのかを分析し，政策的インプリケーションを示していく。

\section{2 研究の方法}

本研究では, 都市のアメニティに対する評価を,アメニティ帰属価額の推計により分析する。また, 消 費者の行動だけでなく，企業行動をもモデルに組み込んだ分析とするため，Roback[5] (1982) の賃金・ 地代の一般均衡モデルを基に分析を行うこととする。いわば市場によるアメニティの評価，都市の評価 を推計しようとするものである。

分析の対象都市は東京都区部・12 政令指定都市とし, 対象期間は第 1 期 (1988・1990 年), 第 2 期 (1993・ 1995 年), 第 3 期 $(1998$ ・ 2000 年) の 3 期とする。

このことにより，最近の 10 年間で, 消費者や企業が, 様々な都市アメニティについてどのように評価 を変えてきたか，また，各都市をどのような順位で評価してきたかを，一般均衡モデルの基礎の下に明 らかにする。

Roback [5]（1982）に基づく日本の都市のアメニティ鹵属価額に関する研究としては，加藤［2］ (1990)，赤井・大竹 [1］（1995），Tabuchi et al. [6（2000)などがある。加藤［2］（1990）は 1985 年 の日本の 336 都市について都市生活の順位付けを行っている。赤井・大竹 [1]（1995）は賃金構造基本 調査の個票データなどを用いて 1984 年の日本の 189 都市について環境評価を導いている。Tabuchi et al. [6]（2000）は標準大都市雇用圈（SMEA）のデータを用いて 1992 年における日本の都市の集積の経 済効果を分析し, 人口が 2 倍になると, 生産性向上のため名目賃金が $10 \%$ 上昇し, 消費の多様性を反映 して実質顀金が 7〜 12\% 下降することを示した。

$*$ 中京大学経済学研究科博士後期課程

1 アメニティとは，「住み心地のよさ」，「快適な居住環境」を構成する複合的な要因の総称である（宮本憲一 [4]（1989））。それは，「自然環境に関するアメニティ」と「社会環境に関するアメニティ」とから構成され， また，都市という視点からは，都市そのものの位置によって決まる「都市固有のアメニティ」と，都市内の 立地点によって決まる「立地点固有のアメニティ」とに類型化される（中村・田淵 [3] (1996))。本研究で は，Roback [5]（1982）に従って，家計にとっての居住環境だけでなく，企業の生産性から見た環境も広

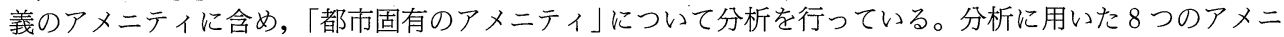
ティ指標のうち，「暖房デグリーデー」だけが「自然環境に関するアメニティ」指標に属し，他は「社会環 境に関するアメニティ」指標である。 
これらの研究に対して本研究の特徵は次のようである。

(1) 先行研究がすべて 1 期だけの分析であったのに対して，3期にわたるアメニティ帰属価額の推計を 行い，さらに，全ての期を 2000 年価格にデフレートして，その推移を観察したこと $(2000$ 年=100)。

(2) (1) に基づき,アメニティの種類ごとの評価の変化により，どのようなアメニティが高い評価を受け るようになってきているかを分析し，また，各都市のアメニティの種類ごとの評価の変化により，そ の都市においてどのようなアメニティを重点的に改善すべきか, という政策的なインプリケーショ ンを示すことができたこと。

(3) 計量分析においては，賃金データを消費者物価地域差指数（家賃を除く。全国平均＝100）により調 整することにより，地域ごとの家計の実質的な予算制約に基づく分析をおこない，また，回帰分析 における説明変数を標準化することにより,変数ごとの分散の差などを調整して分析を行ったこと。

\section{Roback の一般均衡モデル}

Roback [5]（1982）の貨金・地代の一般均衡モデルは次のようである。

\section{1 都市についての仮定}

都市についての仮定は次のょうである。

(1) 多数の都市が存在し，資本と労働の都市間移動は自由である。(開放都市の仮定)

(2) $s$ はアメニティ指標値とし, $\left(S_{1}, S_{2}\right)$ の間で連続的であるものとする。ひとつの都市内での $s$ は, コミュニティに関係なく一定である。

(3) それぞれの都市の住民が消費し, 生産する合成財を $X$ とする。その価格は世界市場で固定され ておりニュメレール財とする。

(4) 住居移動にコストはかからない。

(5) 都市間は通勤できない。(職住一致の仮定)

\section{2 労働者の行動}

労働者についての仮定は次のようである。

(1) 労働者は，同一の嗜好と技能を持っているものとする。

(2) 賃金とは関係なく, 労働者はそれぞれ 1 単位の労働を供給するものとする。

ここで, $x$ を合成財 $X$ の消費量, $l^{c}$ を消費する住宅用土地, $w$ を貨金, $r$ を地代とすると, 労働者は, 次式のとおり，予算制約の下で，効用を最大化するように行動する。

$$
\max U\left(x, l^{c} ; s\right) \quad \text { s.t. } w=x+l^{c} r
$$

したがって均衡状態では, 全ての都市での労働者の効用は等しくなり, 間接効用関数 $V$ は次式の通り 表されることとなる ( $k$ は一定)。

$$
V(w, r, s)=k
$$

\section{3 企業の行動}

企業の生産は, 規模に関して収穫一定であるものとし， $l^{p}$ を生産に使用される土地， $N$ を都市の総労 働者数とすると, 生産物 $X$ の生産関数は次式のようにあらわされる。 


$$
X=f\left(l^{p}, N ; s\right)
$$

このとき企業は，この生産関数のもとで費用を最小化しょうと行動するが，均衡状態での企業利潤は 0 であることから, 生産物 $X$ の単位費用関数は, 次のとおり表すことができる。ただし, 生産物 Xをニュ メレール財とする。

$$
C(w, r ; s)=1
$$

\section{4 均 衡}

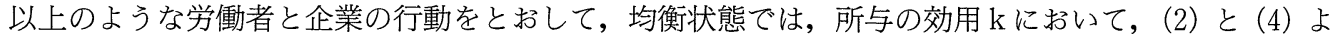
り次式が成り立つ。2

$$
\begin{aligned}
& d w / d s=\left(-V_{s} C_{r}+V_{r} C_{s}\right) / \Delta<0 \\
& d r / d s=\left(-V_{w} C_{s}+V_{s} C_{w}\right) / \Delta>=<0 \\
& \text { ただし } . \Delta=V_{w} C_{r}-V_{r} C_{w}=L(s) V_{w} / X>0
\end{aligned}
$$

ここで, $L(s)$ は，アメニティ $s て ゙$ 利用できる土地の総量 $\left(L(s)=l^{p}+N l^{c}\right)$ である。

\section{5 環境帰属価額の計測}

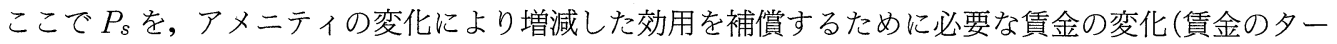
ムで測ったアメニティの限界的な価値）とすれば，ロワの恒等式を用いて，次式を導くことができる。

$$
P_{s} \equiv V_{s} / V_{w}=l^{c}(d r / d s)-d w / d s
$$

(6) 式の右辺の第 1 項はアメニティの差が地代に反映しているという意味で「土地の資本化理論」を，第 2 項はアメニティの差を賃金が補償しているという意味で「補償賃金格差 (均等化差異) 理論」を表して いるということができる。

以上が, Roback [5]（1982）の基本モデルである。

\section{3. 実証分析のためのアメニティ帰属価額の導出}

ここで，ある期における都市 $i$ の $n$ 種類のアメニティ指標のうちの $j$ 番目のアメニティ指標値を $s_{i j}$ とする。当該期におけるアメニティ帰属価額を求めるために， $n$ 種類の $s_{i j}$ を説明変数として，都市ごと の家賃 $r_{i}$ と賃金 $w_{i}$ を被説明変数とする次の回帰分析を, 最小自乗法により行う。ただし $u_{\alpha i}, u_{\beta i}$ は誤差 項である。

$$
\begin{aligned}
& \ln r_{i}=\alpha_{0}+\sum_{j=1}^{n} \alpha_{j} \ln s_{i j}+u_{\alpha i} \\
& \ln w_{i}=\beta_{0}+\sum_{j=1}^{n} \beta_{j} \ln s_{i j}+u_{\beta i}
\end{aligned}
$$

（6）から，アメニティ指標 $s_{j}$ の平均水準での $1 \%$ 変化に対する評価額 $P_{s j}$ は，次の (9) 式のように表す ことができる。ここで， $\bar{l}^{c}, \bar{r}, \bar{w}, \bar{s}$ は，住宅用土地面積，地代，賃金，アメニティの平均值である。

2 (2)，(4) を全微分した連立方程式を $d w / d s, d r / d s$ について解くと，(5) の上の 2 式が得られる。さらにロ ワの恒等式 $\left(l^{c}=-V_{r} / V_{w}\right)$ により，(5) の第 3 式を求めることができる。

${ }^{3}$ （2）を全微分して， $V s$ について解き， $V s / V w$ を変形して，口ワの恒等式 $\left(l^{c}=-V r / V w\right)$ を代入すると (6) が得られる。 


$$
\begin{aligned}
P_{s j} & =\bar{l}^{c} d r /\left(d s_{j} / \bar{s}_{j}\right)-d w /\left(d s_{j} / \bar{s}_{j}\right) \\
& =\bar{l}^{c}\left(d \ln r / d \ln s_{j}\right) \bar{r}-\left(d \ln w / d \ln s_{j}\right) \bar{w} \\
& =\bar{l}^{c} \alpha_{j} \bar{r}-\beta_{j} \bar{w}
\end{aligned}
$$

従って，都市 $i$ におけるアメニティ指標 $s_{j}$ についての相対的評価額（帰属価額）は，

$$
P_{s i j}=P_{s j}\left\{\left(s_{i j}-\bar{s}_{j}\right) / \bar{s}_{j}\right\}
$$

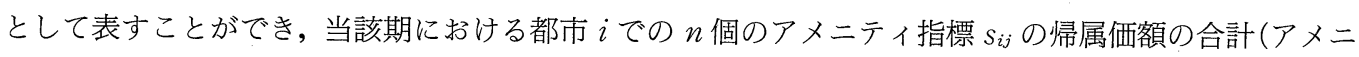
ティの総合評価額）は，次のようである。

$$
A_{i}=\sum_{j=1}^{n} P_{s i j}=\sum_{j=1}^{n}\left(\bar{l}^{c} \alpha_{j} \bar{r}-\beta_{j} \bar{w}\right)\left\{\left(s_{i j}-\bar{s}_{j}\right) / \bar{s}_{j}\right\}
$$

\section{4. 実証分析（13 大都市のアメニティ帰属価額と炎の推移）}

\section{1 分析の対象}

さて，ここで，第 1 期（1988・1990 年），第 2 期（1993・1995 年）, 第 3 期（1998・2000 年）の 3 期に おける日本の大都市のアメニティ帰属価額を推計する。対象都市は, 東京都区部と 12 政令指定都市の計 13 都市である。

\section{2 データ}

データの概要と意味付けは表 1 のとおりである。サンプルが 13 都市と少ないため, 1988 年と 1990 年, 1993 年と 1995 年, 1998 年と 2000 年をそれぞれ 1 期として, 必要な自由度を確保した。

また, 回帰分析上の被説明変数である家貨及び貨金については, 各期ごとに消費者物価地域差指数 (全 国平均 $=100$ 。家賃を除く総合)によって全国平均価格に調整し，さらに，消費者物価指数 $(2000$ 年=100) によりデフレートした後，これを被説明変数として使用した。

さらに, 8 種類のアメニティ指標を説明変数として採用し, その意味付けは表 1 に明示した。各アメニ ティ指標について，分散や変動係数が著しく異なるため，各指標について，次式のように標準化を行っ た後，回帰分析を行い，説明変数間で係数の大小を観察できるようにした。

$$
s_{i j}=50+\left(y_{i j}-\bar{y}_{i j}\right) \times 10 / \sigma_{j}
$$

ただし， $y_{i j}$ は $i$ 都市における $j$ 番目のアメニティ指標， $\overline{y_{j}}$ は $j$ 番目のアメニティ指標の平均値， $\sigma_{j}$ は $j$ 番目のアメニティ指標の標準偏差とする。また, 説明変数の採用にあたって, 説明変数相互間の多重共 線性の影響を排除するため，分散拡大要因（variance inflation factor）の值が 10 未満にとどまるよう 配慮している。

また，(10)，(11）式の適用の際， $i$ 都市の $s_{i j}$ は，例えば，1988・1990 年については， $\left(s_{1988 j}+s_{1990 j}\right) /$ 2 として平均值を用いて， $P_{s i j}, A_{i}$ を求めた。

\section{3 分析の結果}

(7)，(8)に基づく最小自乗法による回帰分析の結果は表 2 の通りである。自由度調整済み決定係数で, 家賃回帰が賃金回帰を上回っているが, 現実には職住一致の仮定が十分満たされていないことなどから， 予想された結果であった。各係数の $t$ 值も $10 \%$ 水準で有意なものがみられるが, 十分ではないものも認 められる。 
表 1 データの出典・年次等

\begin{tabular}{|c|c|c|c|c|c|c|c|}
\hline \multirow{2}{*}{ 指標の名称 } & \multirow{2}{*}{$\begin{array}{c}\text { 指定統計等 } \\
\text { の名称 }\end{array}$} & \multirow{2}{*}{ 指標の説明 } & \multirow{2}{*}{$\begin{array}{l}\text { 変数の } \\
\text { 意味付け }\end{array}$} & \multirow{2}{*}{ 単位 } & \multicolumn{3}{|c|}{ 対象期 } \\
\hline & & & & & 第 1 期 & 第 2 期 & 第 3 期 \\
\hline 家貨 & 家計調査 & 民営家賃/面積 & rent & 円 $/ \mathrm{m}^{2}$ & $\begin{array}{l}1988 \\
1990\end{array}$ & $\begin{array}{l}1993, \\
1995\end{array}$ & $\begin{array}{l}1998 \\
2000\end{array}$ \\
\hline 賃金 & 家計調査 & $\begin{array}{l}\text { 勤め先収入/世帯当り } \\
\text { 有業人員 }\end{array}$ & wage & 円/人 & $\begin{array}{l}1988, \\
1990\end{array}$ & $\begin{array}{l}1993, \\
1995\end{array}$ & $\begin{array}{l}1998, \\
2000\end{array}$ \\
\hline 暖房デグリーデー & 理科年表 & $\begin{array}{l}14^{\circ} \mathrm{C} \text { 下回る温度を } \\
\text { 暖房期間日にわい積 } \\
\text { 算したもの }\end{array}$ & 自然環境 & $\begin{array}{l}\text { デグリー } \\
\text { デー }\end{array}$ & \multicolumn{3}{|c|}{$1961 \sim 1990$} \\
\hline 二酸化硫黄濃度 & $\begin{array}{l}\text { 大都市比較 } \\
\text { 統計年表 }\end{array}$ & & 公害の状況 & $\mathrm{ppm}$ & $\begin{array}{c}1988, \\
1990\end{array}$ & $\begin{array}{c}1993 \\
1995 \\
\end{array}$ & $\begin{array}{c}1998, \\
2000\end{array}$ \\
\hline 公共下水道普及率 & $\begin{array}{l}\text { 下水道統計 } \\
\text { 要覧 }\end{array}$ & 処理区域人口/市域人 & $\begin{array}{l}\text { インフラの整 } \\
\text { 備状況 }\end{array}$ & $\%$ & $\begin{array}{l}1988 \\
1990\end{array}$ & $\begin{array}{l}1993, \\
1995\end{array}$ & $\begin{array}{l}1998 \\
2000\end{array}$ \\
\hline $\begin{array}{l}\text { 第 } 3 \text { 次産業従事者 } \\
\text { 人口比率 }\end{array}$ & $\begin{array}{l}\text { 事業所・企 } \\
\text { 業統計調査 }\end{array}$ & $\begin{array}{l}3 \text { 次産業従業者数/全 } \\
\text { 従業者数 }\end{array}$ & $\begin{array}{l}\text { サービス経済 } \\
\text { 化, 消費の多 } \\
\text { 榚性 }\end{array}$ & $\%$ & 1986 & 1991 & 1999 \\
\hline $\begin{array}{l}\text { 老人・児童福祉施 } \\
\text { 数人当り })\end{array}$ & $\begin{array}{l}\text { 大都市比較 } \\
\text { 統計年表 }\end{array}$ & 同施設数/市域人口 & $\begin{array}{l}\text { 福祉施設整備 } \\
\text { 況 }\end{array}$ & 所/千人 & $\begin{array}{l}1988, \\
1990\end{array}$ & $\begin{array}{l}1993, \\
1995\end{array}$ & $\begin{array}{l}1998, \\
2000\end{array}$ \\
\hline $\begin{array}{l}\text { 就業者大学・大学 } \\
\text { 院卒率 }\end{array}$ & $\begin{array}{l}\text { 就業構造基 } \\
\text { 本調査 }\end{array}$ & $\begin{array}{l}\text { 大学 } \text { •院卒業者数/就業 } \\
\text { 数 }\end{array}$ & 人的資本の集 & $\%$ & 1987 & 1992 & 1997 \\
\hline 有効求人倍率 & $\begin{array}{l}\text { 職業安定業 } \\
\text { 務統計 }\end{array}$ & 求人数/求職者数 & 労働市場の状 & & $\begin{array}{l}1988 \\
1990\end{array}$ & $\begin{array}{l}1993 \\
1995 \\
\end{array}$ & $\begin{array}{l}1998, \\
2000 \\
\end{array}$ \\
\hline $\begin{array}{l}\text { 刑法犯認知件数 } \\
(\text { 千人当 })\end{array}$ & 犯罪統計 & 認知件数/市域人口 & 治安, 安全 & 件/千人 & $\begin{array}{l}1988, \\
1990\end{array}$ & $\begin{array}{l}1993, \\
1995\end{array}$ & $\begin{array}{l}1998, \\
2000\end{array}$ \\
\hline 人口 & $\begin{array}{l}\text { 大都市比較 } \\
\text { 統計年表 }\end{array}$ & 市域内推計人口 & & 人 & $\begin{array}{l}1988, \\
1990\end{array}$ & $\begin{array}{l}1993, \\
1995\end{array}$ & $\begin{array}{l}1998 \\
2000\end{array}$ \\
\hline $\begin{array}{l}\text { 有業者 } 1 \text { 人当り専 } \\
\text { 年住面積 }\end{array}$ & $\begin{array}{l}\text { 住宅 (土地) } \\
\text { 統計調査 }\end{array}$ & $\begin{array}{l}\text { 専用住宅延 } \mathrm{m}^{2} / \text { 世帯当 } \\
\text { 業人員 }\end{array}$ & & $\mathrm{m}^{2} /$ 人 & 1988 & 1993 & 1998 \\
\hline $\begin{array}{l}\text { 消費者物価地域差 } \\
\text { 指数 }\end{array}$ & $\begin{array}{l}\text { 消費者物価 } \\
\text { 指数年報 }\end{array}$ & $\begin{array}{l}\text { 全国平均 }=100 \text {,家賃を } \\
\text { 除〈総合 }\end{array}$ & & - & $\begin{array}{c}1988 \\
1990\end{array}$ & $\begin{array}{c}1993 \\
1995 \\
\end{array}$ & $\begin{array}{c}1998 \\
2000 \\
\end{array}$ \\
\hline 消費者物価指数 & $\begin{array}{l}\text { 消費者物価 } \\
\text { 指数年報 }\end{array}$ & 2000 年 $=100$, 総合 & & - & $\begin{array}{l}1988 \\
1990\end{array}$ & $\begin{array}{l}1993, \\
1995\end{array}$ & $\begin{array}{l}1998, \\
2000\end{array}$ \\
\hline
\end{tabular}

ここで（9）によりアメニティ指標ごとの帰属価額を求めたものが表 3 と図 1 である。下水道普及率, 大学・大学院就業者率などが上昇傾向を示しており，アメニティとしてのインフラの整備や人的資本の 水準などが高く評価されるようになってきていることが示されている。下水道普及率や大学・大学院卒 業率の帰属価額が上昇を示していることから, 政策的インプリケーションとして, 地方政府には，イン フラなどの基盤整備や教育環境などの分野に重点を置いた施策が求められているといえる。

また，直感的に予測される符合と反対の評価が推計されているアメニティ指標もあるが，企業のアメ ニティに対する評価もモデルに組み込まれていることを考慮すれば,解釈が可能であると考えられる。例 えば，老人・児童福祉施設数が第 3 期において負の評価を得ているのは，企業にとって税負担なども含 めて，生産性にマイナスに作用していることなどが考えられる。

さらに，(11)により都市毎のアメニティ総合評価額を求め, 各期ごとに降順でしめしたのが表 4 と図 2 である。東京都区部, 横浜市や福岡市などが, 順位も含めて上昇傾向にあるのに対して, 大阪市・京都 
表 2 回㷌分析の結果（**は $5 \%$ の水準で，* は $10 \%$ 水準で有意であることを示す。）

（1）家賃を被説明変数とした重回帰分析の結果

\begin{tabular}{|c|c|c|c|c|c|c|}
\hline & \multicolumn{2}{|c|}{ 第 1 期 } & \multicolumn{2}{|c|}{ 第 2 期 } & \multicolumn{2}{|c|}{ 第 3 期 } \\
\hline 説明変数 & 係数 & $t$ 値 & 係数 & $t$ 值 & 係数 & $t$ 值 \\
\hline 暖房 DD & -0.361 & -1.082 & -0.234 & -0.765 & $-0.758^{* *}$ & -2.108 \\
\hline 二酸化硫黄濃度 & -0.172 & -0.432 & $0.524^{*}$ & 1.879 & 0.132 & 0.445 \\
\hline 下水道普及率 & -0.022 & -0.104 & $0.293^{*}$ & 1.999 & $0.300^{*}$ & 1.817 \\
\hline 第 3 次産業従業者率 & -0.239 & -1.062 & -0.163 & -0.901 & 0.078 & 0.318 \\
\hline 老人・児童福祉施設数 & -0.323 & -1.099 & 0.093 & 0.385 & -0.264 & -1.071 \\
\hline 大学・院卒業率 & $0.675^{* *}$ & 2.116 & $0.791^{* *}$ & 3.698 & $0.756^{* *}$ & 2.810 \\
\hline 有効求人倍率 & $0.502^{*}$ & 1.718 & 0.057 & 0.250 & 0.139 & 0.489 \\
\hline 刑法犯認知件数 & -0.052 & -0.196 & -0.400 & -1.499 & -0.289 & -0.836 \\
\hline 決定係数 & \multicolumn{2}{|c|}{0.667} & \multicolumn{2}{|c|}{0.767} & \multicolumn{2}{|c|}{0.705} \\
\hline 自由度調整済み決定係数 & \multicolumn{2}{|c|}{0.476} & \multicolumn{2}{|c|}{0.657} & \multicolumn{2}{|c|}{0.566} \\
\hline サンプル数 & \multicolumn{2}{|c|}{23} & \multicolumn{2}{|c|}{26} & \multicolumn{2}{|c|}{26} \\
\hline
\end{tabular}

（2）賃金を被説明変数とした重回帰分析の結果

\begin{tabular}{|c|c|c|c|c|c|c|}
\hline \multirow[b]{2}{*}{ 説明変数 } & \multicolumn{2}{|c|}{ 第 1 期 } & \multicolumn{2}{|c|}{ 第 2 期 } & \multicolumn{2}{|c|}{ 第 3 期 } \\
\hline & 係数 & $t$ 值 & 係数 & $t$ 值 & 係数 & $t$ 值 \\
\hline 暖房 DD & 0.078 & 0.600 & -0.022 & -0.162 & -0.079 & -0.589 \\
\hline 二酸化硫黄濃度 & $-0.429 * *$ & -2.766 & $-0.306^{* *}$ & -2.448 & $0.247^{* *}$ & 2.213 \\
\hline 下水道普及率 & 0.018 & 0.219 & -0.033 & -0.500 & -0.040 & -0.643 \\
\hline 第 3 次産業従業者率 & -0.197 & -2.250 & -0.097 & -1.200 & 0.087 & 0.941 \\
\hline 老人・児童福祉施設数 & $-0.315^{* *}$ & -2.754 & -0.072 & -0.670 & 0.084 & 0.915 \\
\hline 大学・院卒業率 & $0.456^{* *}$ & 3.673 & $0.235^{* *}$ & 2.452 & 0.039 & 0.386 \\
\hline 有効求人倍率 & 0.148 & 1.300 & -0.074 & -0.717 & 0.061 & 0.575 \\
\hline 刑法犯認知件数 & $0.285^{* *}$ & 2.742 & $0.317^{* *}$ & 2.656 & -0.141 & -1.088 \\
\hline 決定係数 & \multicolumn{2}{|c|}{0.658} & \multicolumn{2}{|c|}{0.430} & \multicolumn{2}{|c|}{0.447} \\
\hline 自由度調整済み決定係数 & \multicolumn{2}{|c|}{0.463} & \multicolumn{2}{|c|}{0.163} & \multicolumn{2}{|c|}{0.187} \\
\hline サンプル数 & \multicolumn{2}{|c|}{23} & \multicolumn{2}{|c|}{26} & \multicolumn{2}{|c|}{26} \\
\hline
\end{tabular}

表 3 アメニテイ指標別帰属価額の推移（2000 年価格）

(単位：円)

\begin{tabular}{l|r|r:r}
\hline \multirow{2}{*}{ アメニティ指標 } & \multicolumn{3}{|c}{ アメニティ指標帰属価額 } \\
\cline { 2 - 4 } & 第 1 期 & 第 2 期 & 第 3 期 \\
\hline 暖房 DD & $-53,733$ & $-13,976$ & $-46,169$ \\
二酸化硫黄濃度 & 124,494 & 146,604 & $-66,572$ \\
下水道普及率 & $-7,483$ & 37,170 & 41,048 \\
第3 次産業従業者率 & 44,451 & 16,793 & $-20,455$ \\
老人・児童福祉施設数 & 75,726 & 31,779 & $-52,038$ \\
大学・院卒業率 & $-93,190$ & $-4,554$ & 58,960 \\
有効求人倍率 & $-7,718$ & 29,084 & $-6,523$ \\
刑法犯認知件数 & $-95,908$ & $-139,070$ & 17,900 \\
\hline
\end{tabular}




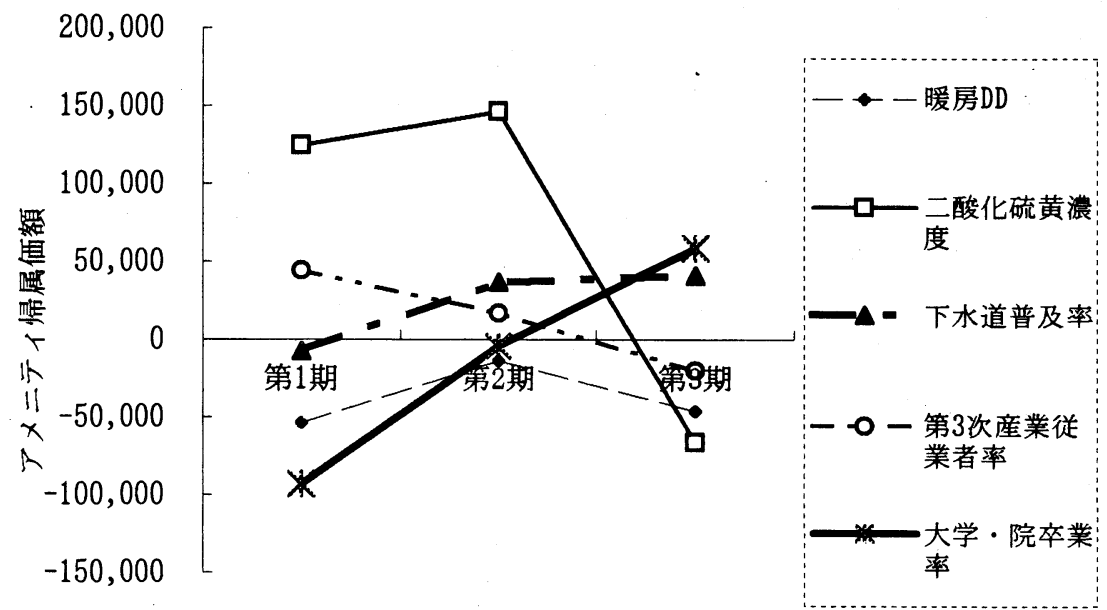

図 1 主なアメニティ指標別帰属価額の推移

表 4 大都市アメニティ総合評価額順位の推移

\begin{tabular}{|c|c|c|c|c|c|c|}
\hline \multirow{2}{*}{ 順位 } & \multicolumn{2}{|c|}{ 第 1 期 } & \multicolumn{2}{|c|}{ 第 2 期 } & \multicolumn{2}{|c|}{ 第 3 期 } \\
\hline & 都市名 & 評価額 & 都市名 & 評価額 & 都市名 & 評価額 \\
\hline 1 & 京 都 & 33,581 & 横 浜 & 51,770 & 横 浜 & 22,034 \\
\hline 2 & 仙 台 & 26,186 & 都区部 & 41,051 & 福 岡 & 17,988 \\
\hline 3 & 大 阪 & 23,754 & 名古屋 & 22,924 & 川 崎 & 14,509 \\
\hline 4 & 神 戸 & 11,386 & 川 崎 & 16,096 & 都区部 & 13,488 \\
\hline 5 & 名古屋 & 6,129 & 神 戸 & 9,974 & 神 戸 & 7,286 \\
\hline 6 & 横 浜 & 4,104 & 京 都 & 9,234 & 北九州 & 4,273 \\
\hline 7 & 北九州 & $-2,237$ & 広 島 & 2,911 & 名古屋 & 3,104 \\
\hline 8 & 都区部 & $-2,455$ & 千 葉 & $-3,649$ & 千 葉 & -536 \\
\hline 9 & 川崎 & $-2,749$ & 大 阪 & $-6,641$ & 仙 & $-3,048$ \\
\hline 10 & 広 島 & $-9,019$ & 札 幌 & $-15,969$ & 大 阪 & $-3,188$ \\
\hline 11 & 福 岡 & $-17,224$ & 仙 台 & $-28,703$ & 京 都 & $-11,798$ \\
\hline 12 & 札 幌 & $-58,362$ & 北九州 & $-30,832$ & 札 幌 & $-30,930$ \\
\hline 13 & - & - & 福 岡 & $-68,164$ & 広 島 & $-33,181$ \\
\hline
\end{tabular}

市などが下降を示しているのが注目される。これらに対して名古屋市は安定した正の評価を受けている。

そこで, 都市別アメニティ総合評価額が上昇している横浜市と福岡市の 2 都市, 下降している京都市 と大阪市の 2 都市について, アメニティ指標別の増減内訳を示したのが表 5 である。横浜市については, 下水道普及率や大学・大学院卒業率の上昇などが, 福岡市については二酸化硫黄濃度の改善や下水道普 及率などが総合評価額の上昇に寄与していることが示されている。また，京都市と大阪市については大 学・大学院卒業率の下降などが, 総合評価額の下降を惹起していると考えられる。こうした分析により, 各都市においてどのようなアメニティの改善に重点を置くべきかという政策的インプリケーションを得 ることができる。 


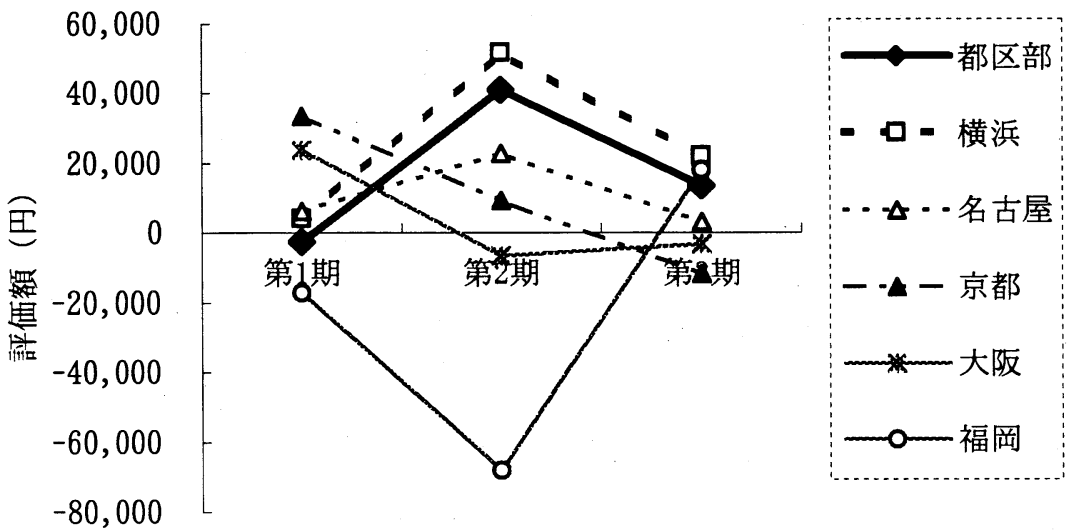

図 2 主要都市のアメニティ総合評価額の推移

\section{5. 結論と今後の課題}

\section{1 結論}

本研究では，Roback [5）(1982）の賃金・地代の一般均衡モデルに基づき，計量経済学的手法による 日本の大都市のアメニティ評価を行った。これにより，次の諸点が明らかになった。

(1) 2000 年までの約 10 年のアメニティの種類別に評価の推移をみると，インフラの整備や人的資本 の水準などの評価が高まっている傾向が示された。

(2) 都市別のアメニティ総合評価については，東京都区部・横浜市・福岡市などが順位を高める傾向 があるのに対し，大阪市・京都市などは下降傾向が示される結果となった。

(3) 説明変数を家賃とした場合と，貨金とした場合の回帰分析の結果は，自由度調整済み決定係数な ぞ，前者のほうが高い水準となる傾向が見られた。賃金については，職住一致の仮定が現実には 満たされていないことや，労衔者の属性などがコントロールされていないことなどにより，低い 説明力にとどまっているものと考えられる。

(4) しかし，アメニティ指標別の帰属価額の推移や，都市毎のアメニティ総合評価額などを分析する ことにより，政策的インプリケーションとして，インフラなどの基盤整備や教育環境などの分野 に重点を置いた施策が求められていることなどを示すことができた。

\section{2 今後の課題}

今後の課題として，次のような点を指摘しておきたい。

(1) 被説明変数について, データとして, 家計調査を利用しているためサンプル数などが十分でなく, 他の統計調査の利用を検討していく必要がある。さらに, マイクロデータの利用や, 都市圈を単 位とした分析などを検討していきたい。

(2) また, 表 6 に, 各期の都市毎の人口成長率とアメニティ総合評価額との相関係数を示した。第 1 期 と第 2 期においては相関係数が負であったが，第 3 期に正に転じていることが注目される。これ は，土地神話の崩壊がいよいよ明らかになるにつれて，消費者が，地価高騰の期待よりも，客観 的なアメニテイ評価により都市を選好するようになったためとも解釈できるが，さらに多方面か らの実証が必要である。いずれにしても，アメニティ評価と人口移動との関係に着目した研究も 
表 54 都市のアメニティ別帰属価額の推移

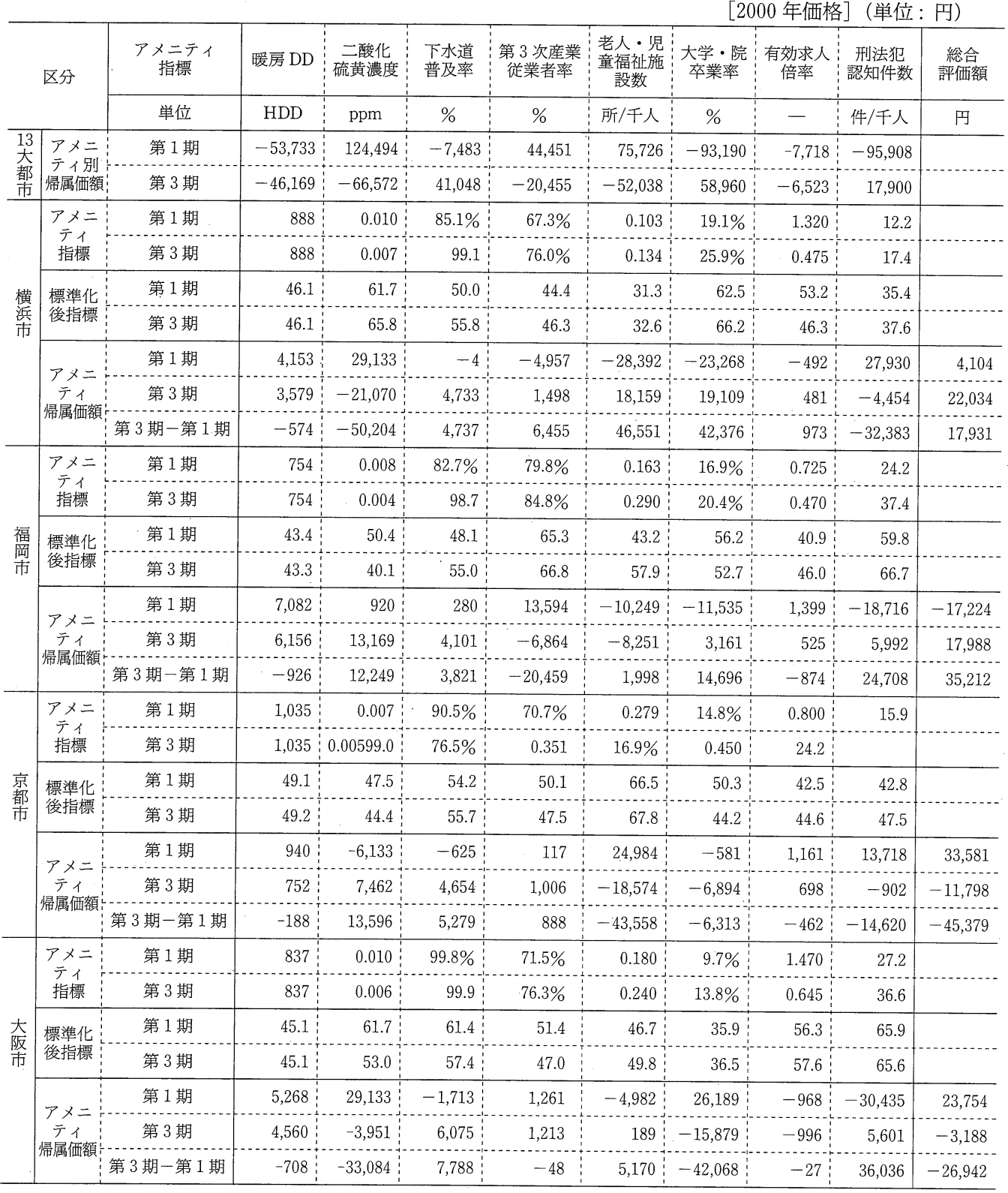

表 6 都市別アメニティ総合評価額と人口増加率の相関関係の推移

\begin{tabular}{c|c|c|c}
\hline \multirow{2}{*}{ 区 分 } & 第 1 期 & 第 2 期 & 第 3 期 \\
\cline { 2 - 4 } & 1988,1990 年 & 1993,1995 年 & 1998,2000 年 \\
\hline 相関係数 & -0.458 & -0.333 & 0.429 \\
\hline
\end{tabular}


行っていく必要があると考えられる。

\section{参考 文 献}

［1］赤井伸郎・大竹文雄「地域間環境格差の実証分析」『日本経済研究』No. 30, 1995 年, pp. 94-137.

［2］加藤尚史「都市生活の質の指標化」『一橋論叢』第 103 巻, 1990 年, pp. 690-714.

[3 ］中村良平・田淵隆俊『都市と地域の経済学』有斐閣, 1996 年, pp. 277-279.

[ 4 ］宮本憲一『環境経済学』岩波書店, 1989 年, pp. 121-124.

[ 5 ] Roback, Jennifer, "Wages, Rents, and the Quality of Life", Journal of Political Economy, Vol. 90, No. 6, 1982, pp. 1257-1278.

[6] Tabuchi, Takatoshi and Yoshida, Atsushi, "Separating Urban Agglomeration Economies in Consumption and Production", Journal of Urban Economics, 48, 2000. pp. 70-84. 


\title{
Valuation of Amenities of Great Japanese Cities Based on General Equilibrium Model
}

\author{
Sumio OsHIRO*
}

In this study, I estimated implicit prices of amenities of great Japanese cities based on Roback (1982)'s model. She proposed general equilibrium model of wages and rents setting both behaviors of consumers and firms.

Comparing with some papers that analyzed implicit prices of amenities of Japanese cities based on her models, this study differs from those in following three points.

(1) This study estimated implicit prices of amenities in three terms and observed the changes of those.

(2) By (1), this study shows the changes of implicit prices of each kind of amenity indicators, and the changes of city rankings on integrated amenity valuation. Also it proposes policy implications to make amenities better for each cities.

(3) As for econometric analysis, I deflate the wages by regional difference index of consumer prices, and I make amenity indicators standardized.

As empirical study, I estimated implicit prices of 8 kinds of amenities and integrated amenity prices of 13 cities on 3 terms.

I can conclude as follows.

(1) As results, we have been appreciating the infrastructure constructions and accumulations of human capitals more.

(2) As for integrated amenity valuation, we have been appreciating Tokyo, Yokohama and Fukuoka more, but not Osaka and Kyoto.

(3) The results of regressions show that wage regression made worse performance than rent regression.

(4) Anyway, by this analysis I can propose policy implication that those are important for local government to improve infrastructure and educational environment.

* Graduate School of Economics, Chukyo University. 